\title{
NARKOTIKŲ VARTOTOJŲ MIRTINGUMAS LIETUVOJE (KOHORTINIS TYRIMAS)
}

\author{
Rimantas Stukas, Aušra Beržanskytė, Valerij Dobrovolskij, \\ Lina Ignatavičiūtė, Ernestas Jasaitis \\ Vilniaus universitetas, Medicinos fakultetas, Sveikatos mokslu institutas
}

Raktažodžiai: narkotikų vartotojai, mirtingumas, kohortinis tyrimas.

\section{Santrauka}

Tyrimo tikslas - nustatyti narkotinių ir psichotropiniu medžiagų vartotojų mirtingumą Lietuvoje ir išanalizuoti mirčių priežastis.

Medžiaga ir tyrimo metodai. Atliktas perspektyvinis kohortinis tyrimas (angl. prospective study). Tyrimo tikslinè grupe - Lietuvos Respublikos piliečiai, kurie 2017 m. kreipési ị Lietuvos asmens sveikatos priežiūros ịstaigas dèl psichikos ir elgesio sutrikimų, kai vartoja narkotines ir psichotropines medžiagas. Tyrimo duomenų šaltiniai: Elektroninès sveikatos paslaugų ir bendradarbiavimo infrastruktūros informacinè sistema (e. sveikata). Papildomas duomenų apie asmenų narkotikų vartojimą šaltinis - asmenų, kurie kreipiasi ị asmens sveikatos priežiūros ịstaigas dèl psichikos ir elgesio sutrikimų, kai vartoja narkotines ir psichotropines medžiagas, stebèsenos informacinè sistema. Tyrimo rezultatų standartizavimo procedūrai atlikti naudojama kontroliné kohorta - Europos standartiné populiacija.

Rezultatai ir išvados. Kohortinio narkotikų vartotojų Lietuvoje mirtingumo tyrimo tiriamąją populiaciją sudaré 231 asmuo, iš jų 179 vyrai ir 52 moterys. Tiriamuoju laikotarpiu (2018-2020 m.) analizuota 14 tyrimo dalyvių mirčių atvejų: devyni atvejai vyrų ir penki moterų. Tai sudare 6,1 proc. visų itrauktų i tyrimą dalyvių - 5,0 proc. visu itrauktų vyrų ir 9,6 proc. itrauktų moterų, santykis 1,9 karto. Daugiausia mirusių tiriamujjų (9 asm., 64 proc.) buvo registruoti dèl psichikos ir elgesio sutrikimų, vartojant opioidus. Bendras mirusiųjų amžiaus vidurkis - 36,4 metų, vyrų - 38,2 metų, moterų - 33,2 metų (palyginimui vyrų vidutinè tikètina gyvenimo trukmé Lietuvoje $2019 \mathrm{~m}$. buvo 71,5 metų, o moteru - 81 metai). Per visą tyrimo laikotarpi Lietuvos tirtos kohortos mirtingumas buvo 19,7/1000 asm. Standartizavus pagal amžių, standartu imant Europos populiaciją, mirtingumas $21,9 / 1000$ asmens metų, vyrų - 13,3/1000 asmens metų, moterų 30,5/1000 asmens metų.

\section{Ivadas}

Narkotinių ir psichotropinių medžiagų (narkotikų) vartojimas - sudetinga socialinè ir sveikatos problema, su kuria susiduria milijonai žmonių visame pasaulyje. Piktnaudžiavimas šiomis medžiagomis yra viena iš pagrindinių visuomenès sveikatos ir socialinių problemų Europos Sajungoje ir už jos ribų.

Mirtys, susijusios su narkotikų vartojimu, yra kompleksinis reiškinys, apimantis mirtis dèl apsinuodijimo (perdozavimo), ilgalaikio narkotikų vartojimo ar priklausomybès nuo jų, bei mirtis, netiesiogiai susijusias su narkotikais (pvz., mirtis nuo užkrečiamųjų ligų, plintančių asmenims keičiantis nesteriliais švirkštais (pvz., AIDS ar C hepatito) ar nelaimingų atsitikimų bei smurto ir savižudybių dèl narkotikų poveikio).

Pasaulio sveikatos organizacijos skaičiavimais, 450 tūkst. mirčių, registruotų pasaulyje 2015 m., galëjo būti susijusios su narkotikų vartojimu. Iš jų 167 tūkst. mirčiu buvo tiesiogiai nulemtos narkotikų vartojimo, pavyzdžiui, mirtini apsinuodijimo (perdozavimo) atvejai. Mažinti tokių mirčių skaičių yra pagrindinis visuomenès sveikatos politikos uždavinys Europoje ir visame pasaulyje. Mirtys, įvykusios dèl daugelio kitų priežasčių, pavyzdžiui, tokių ligų kaip ŽIV ar C hepatitas, užsikrètimas kuriomis susijęs su nesaugių narkotikų injekcijų praktika, netiesiogiai priskiriamos mirtims, susijusioms su narkotikų vartojimu. Apibendrinant - tiesioginès ar netiesioginès mirtys dèl neteisèto narkotikų vartojimo sudaro didelę visų išvengiamų ar per anksti ịvykusių suaugusiųjų mirčių dali visame pasaulyje. Daugelyje Europos šalių jis apima reikšmingą prarastų gyvenimo metų skaičių.

Duomenys apie mirtis, susijusias su narkotikų vartojimu, yra vienas iš penkių Europos narkotikų ir narkomanijos stebėsenos centro nustatytų epidemiologinių rodiklių, kuriuos periodiškai turi teikti ES valstybès narès, tarp jų ir Lietuva. 
Vienas iš šio epidemiologinio indikatoriaus komponentų yra bendro didelès rizikos narkotinių ir psichotropinių medžiagų vartotojų mirtingumo stebèsena. Bendro mirtingumo arba dèl bet kokių priežasčiu įvykusių ir grupei priskirtų asmenų mirčių stebėsena vykdoma atliekant kohortinius tyrimus. Šių tyrimų metu mirčių arba gyventojų registre esantys duomenys susiejami su kitais asmens duomenimis, dažniausiai gaunamais iš sveikatos priežiūros įstaigų ar informacinių sistemų, kuriose kaupiami duomenys apie asmenis, vartojusius ar vartojančius narkotines ir psichotropines medžiagas. Susiejant skirtingų šaltinių duomenis, yra galimybė patikrinti asmens, kuris kuriuo nors metu kreipèsi ị sveikatos priežiūros ịstaigas dèl narkotinių ir psichotropinių medžiagų vartojimo, statusą, t. y. identifikuoti, ar asmuo yra gyvas, ar miręs, o jei miręs, tai dèl kokių priežasčių.

Tyrimo tikslas - nustatyti narkotinių ir psichotropinių medžiagų vartotojų mirtingumą Lietuvoje ir išanalizuoti mirčių priežastis.

\section{Tyrimo medžiaga ir metodai}

Tyrimo rūšis - perspektyvinis kohortinis tyrimas (angl. prospective study), t. y. tyrimas pradedamas suformavus tiriamujų kohortą, asmens mirtis nustatoma vẻliau, nei tyrimo pradžia.

Tyrimo tikslinè grupe (tiriamoji kohorta arba tiriamoji populiacija) - Lietuvos Respublikos piliečiai, kurie 2017 m. kreipèsi ị Lietuvos asmens sveikatos priežiūros ịstaigas dèl psichikos ir elgesio sutrikimų, kai vartoja narkotines ir psichotropines medžiagas.

Tyrimo pradžios - asmens įtraukimo (registracijos) i tyrimą pradžios laikas (periodas): nuo $2017 \mathrm{~m}$. sausio $1 \mathrm{~d}$. iki 2017 m. gruodžio 31 d. ịskaitytinai.

Tyrimo laikotarpis (tiriamosios kohortos asmenų stebèjimo ir (ar) statuso tikrinimo laikotarpis) nuo $2018 \mathrm{~m}$. sausio $1 \mathrm{~d}$. iki $2020 \mathrm{~m}$. gruodžio $31 \mathrm{~d}$.

Tyrimo duomenų šaltinis: Elektroninès sveikatos paslaugų ir bendradarbiavimo infrastruktūros informacinè sistema (e. sveikata). ${ }^{1}$ Duomenų tvarkytojas - VI „ „Registrų centras". ${ }^{2}$ Papildomas duomenų šaltinis apie asmenų narkotikų vartojimą - Asmenų, kurie kreipiasi į asmens sveikatos priežiūros ịstaigas dèl psichikos ir elgesio sutrikimų, kai vartoja narkotines ir psichotropines medžiagas, stebėsenos informacinè sistema. Duomenų tvarkytojas - Valstybinis psichikos sveikatos centras. ${ }^{3}$

${ }^{1}$ Elektroninès sveikatos paslaugų ir bendradarbiavimo infrastruktūros informacinèje sistemoje (e. sveikata) centralizuotai Lietuvos mastu kaupiami skirtingų šaltinių teikiami ịvairūs su asmens sveikata susiję duomenys, tarp jų ir duomenys apie mirtį, todèl to paties asmens duomenų susiejimas yra automatinis vienoje informacinejje sistemoje.

${ }^{2}$ Adresas internete: https://www.esveikata.lt/

${ }^{3}$ Adresas internete: https://vpsc.lrv.lt/
Tyrimo atlikimo būdas - skirtingų duomenų šaltinių duomenų susiejimas (angl. data linkage).

I tyrimo tikslinę grupę ịtraukiami asmenys, atitinkantys visus išvardytus kriterijus:

1. Asmuo - Lietuvos Respublikos pilietis, kurio žinomas asmens kodas.

2. Asmuo $2017 \mathrm{~m}$. kreipèsi ị asmens sveikatos priežiūros įstaigą dẻl psichikos ir elgesio sutrikimų, kai vartoja narkotines ir psichotropines medžiagas.

3. Asmens amžius - nuo 15 iki 49 metų.

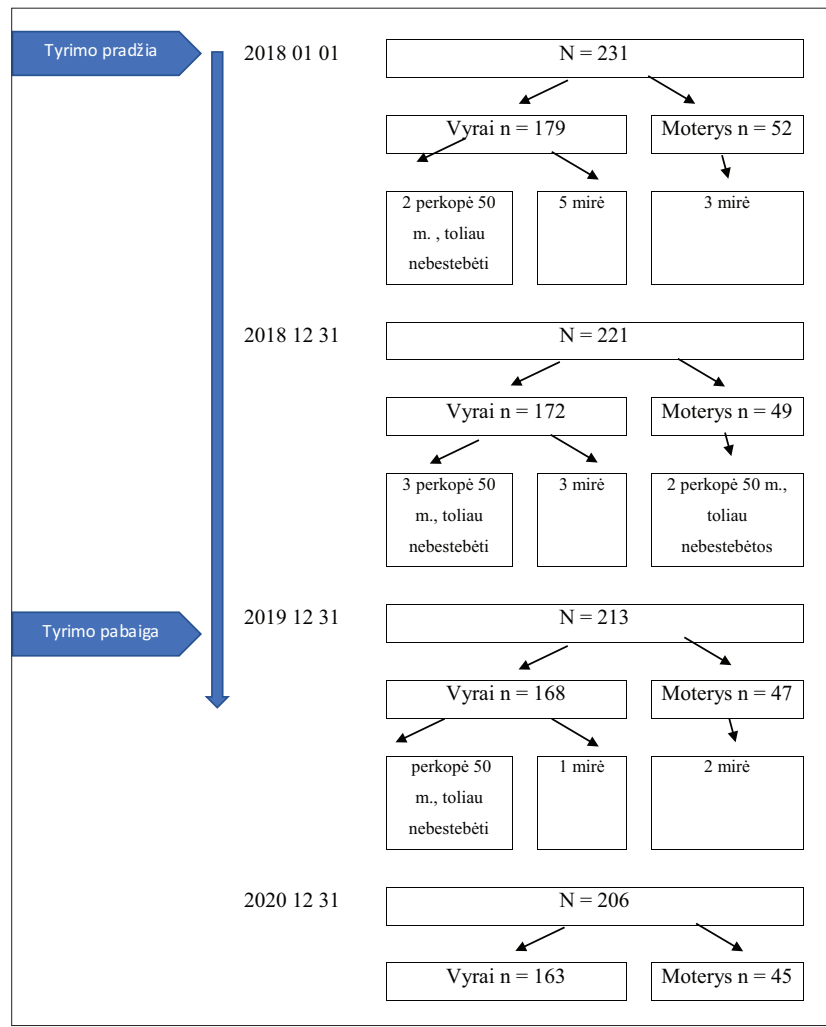

1 pav. Tyrimo dalyvių skaičiaus dinamika tiriamuoju laikotarpiu

1 lentelė. Mirusių 2018-2020 m. tiriamųjų atvejų pasiskirstymas pagal lytị ir priklausomybės ligos diagnozę.

\begin{tabular}{|l|c|c|c|}
\hline Ligos kodas pagal TLK-10-AM & Vyrai & $\begin{array}{c}\text { Mote- } \\
\text { rys }\end{array}$ & $\begin{array}{c}\text { Iš } \\
\text { viso }\end{array}$ \\
\hline $\begin{array}{l}\text { F11 - psichikos ir elgesio sutrikimai, } \\
\text { vartojant opioidus }\end{array}$ & 5 & 4 & 9 \\
\hline $\begin{array}{l}\text { F15 - psichikos ir elgesio sutrikimai, } \\
\text { vartojant stimuliatorius, taip pat kofeiną }\end{array}$ & 1 & 0 & 1 \\
\hline $\begin{array}{l}\text { F19-psichikos ir elgesio sutrikimai, } \\
\text { vartojant kelis narkotikus ir kitas psi- } \\
\text { choaktyviąsias medžiagas }\end{array}$ & 3 & 1 & 4 \\
\hline Iš viso & 9 & 5 & 14 \\
\hline
\end{tabular}


4. Asmens amžius mirties dieną - iki 50 metų.

5. Asmeniui nustatyta liga žymima TLK-10-AM kodais: F11, F12, F14, F15, F16, F18 ir F19.

Tyrimui naudojami duomenys apie tyrimo dalyvị:

1. Bendrieji asmens duomenys:

a) unikalus tiriamojo numeris;

b) Lietuvos Respublikos piliečio asmens kodas (tik mirusio asmens);

c) asmens lytis;

d) gimimo metai.

2. Duomenys apie ASPI , asmenį, narkotikų vartojimo ipročius, sergamumą užkrečiamosiomis ligomis ir kt.:

a) asmens kreipimosi (priklausomybès ligos diagnozès nustatymo ASPİ) data (duomenų formos užpildymo data);

b) nustatytas ligos (priklausomybès ligos) kodas pagal TLK-10-AM (tik F11, F12, F14, F15, F16, F18 ir F19 kodai).

3. Duomenys apie asmens mirtí, mirties priežastis ir aplinkybes:

a) mirties data;

b) pagrindinès mirties priežasties kodas(-ai) pagal TLK10-AM;

c) tarpinès mirties priežasties kodas(-ai) pagal TLK10-AM;

d) tiesioginès mirties priežasties kodas pagal TLK10-AM;

e) kitos svarbios patologinès būklès, galëjusios sukelti mirti, bet nesusijusios su pagrindine mirties priežastimi, kodas (-ai) pagal TLK-10-AM.

Analizuojant tyrimo dalyvių mirties atvejus, šie pagal mirties priežastis, užkoduotas pagal TLK-10 klasifikaciją, skirstomi ị šias grupes:

a) ŽIV/AIDS (TLK-10 kodai B20-B24);

b) tiesioginès asmenų mirtys dèl narkotinių ir psichotropinių medžiagų vartojimo (TLK-10 kodai: X40-X44, X49, X60-X64, X85 Y10-Y14, Y19, F11-F16, F18 ir F19, T40);

c) kitos mirties priežastys;

d) mirties priežastis nenustatyta (TLK-10 kodai: R00R99).

Tyrimo rezultatų standartizavimo procedūrai atlikti naudojama kontrolinè kohorta - Europos standartiné populiacija (angl. European standard population).

\section{Rezultatai ir jų aptarimas}

Tyrimo populiaciją, atlikus pirminių duomenų filtravimą ir atranką (iš viso gauti ịrašai apie 263 asmenis), sudarè 231 asmuo, iš jų 179 vyrai ir 52 moterys. Jauniausiojo amžius buvo 15 metų, vyriausiojo - 49 metai, bendras tiriamuju amžiaus vidurkis $2017 \mathrm{~m}$. - 34,1 metų, vyrų - 34,6 metų, moterų - 32,4 metų. Daugiausia (45 proc.) tiriamųų buvo registruoti dèl psichikos ir elgesio sutrikimų, kai vartojo kelis narkotikus ir kitas psichoaktyviąsias medžiagas, kiti (41 proc.) dèl psichikos ir elgesio sutrikimų, kai vartojo opioidus.

Tyrimo metu tiriamosios populiacijos dydis kito. Šio kitimo dinamika pateikiama 1 paveiksle.

Pagal amžiu ir gyvybès statusą iki tyrimo pabaigos stebeti 208 tiriamieji - 163 vyrai ir 45 moterys. Per tyrimo laikotarpi mire 16 stebimo amžiaus tyrimo dalyvių, tačiau du iš jų perkopė viršutinę tyrimo metodikoje nustatytą amžiaus ribą (tyrimo laikotarpiu asmeniui sukako 50 metų ir daugiau), todèl toliau bus analizuojamos 14 tiriamų asmenų mirtys ir jų priežastys. Iš 14 tyrimo dalyvių mirčių devynios registruotos vyrų, penkios - moterų. Tai sudare 6,1 proc. visų itrauktų i tyrimą dalyvių $-5,0$ proc. visų įtrauktų vyrų ir 9,6 proc. įtrauktų moterų, santykis 1,9 karto. Jauniausio amžiaus asmuo buvo 25 metų, vyriausio - 48 metų. Bendras mirusiujų amžiaus vidurkis - 36,4 metų, vyrų - 38,2 metų, moterų 33,2 metų. Daugiausia mirusių tiriamujų buvo registruoti dèl psichikos ir elgesio sutrikimų, kai vartojo opioidus - 9 asmenys (64 proc.) (1 lentelè). Daugiausia asmenų mirčių (8 atvejai) registruota pirmaisiais stebejjimo metais (2018 m.).

Iš 14 mirusių tiriamụjų dviejų tiesioginè mirties priežastis buvo psichotropinių medžiagų vartojimas (mirtinas apsinuodijimas), iš jų 1 atveju mirties liudijime nurodytas metadonas, kitu atveju - kiti ir nepatikslinti narkotikai. Trijų tiriamujų mirties priežastis buvo susijusi su ŽIV liga, šie trys asmenys vartojo opiatus. Devynių asmenų mirtį lėmè kitos priežastys. Iš kitų mirčiu dažniausia ( 8 atv.) mirties priežastis - ịvairi lėtiné patologija, kaip antai, kardiomiopatija, koronarų trombozè, kraujavimas, septicemija, asfiksija, inkstų ligos. Keturiais atvejais mirties liudijime tarp kitų mirties priežasčių nurodoma, kad mirtị galbūt lėmė asmens sirgimas C hepatitu (užsikrètimas šia liga galèjo būti susijęs su narkotikų vartojimu), o keturiais atvejais mirties liudijime nurodyta, kad asmuo gydėsi nuo narkomanijos ar dalyvavo pakaitinio gydymo metadonu programoje (2 lentelè).

Per visą tyrimo laikotarpi Lietuvos tirtos kohortos mirtingumas buvo 19,7/1000 asm. Vyrų mirtingumas buvo didesnis nei moteru (3 lentelè). Atkreiptinas dėmesys, kad moterų tyrime dalyvavo tris kartus mažiau, todèl pasikliautinasis intervalas nurodo labai plačias ribas ir negalima nustatyti statistiškai reikšmingo skirtumo tarp lyčių. Palyginti su to amžiaus bendros populiacijos Lietuvoje mirtingumu ${ }^{4}$, šios kohortos rodiklis buvo didesnis maždaug 5-14 kartų, o moterų didesnis daugiau kaip 40 kartų. Reikia atsižvelgti ị tai, kad bendrosios gyventojų populiacijos lygmeniu rodikliai gali būti sušvelninti, nes neįmanoma tiksliai suskaičiuoti asmens rizikos laiko.

\footnotetext{
${ }^{4}$ Higienos institutas. Sveikatos statistika. Interneto prieiga: https://stat.hi.lt/default.aspx?report_id=229, žiūrèta 20210429.
} 
Standartizavus pagal amžių, standartu imant Europos populiaciją, mirtingumas $21,9 / 1000$ asmens metų, vyrų - 13,3/1000 asmens metu, moteru $30,5 / 1000$ asmens metu (4 lentelè). Šis rodiklis pirmaisiais stebejjimo metais nustatytas didžiausias. Per 2019 m., kai neregistruota nè viena moters mirtis, bendras rodiklis buvo mažiausias iš stebètu trejų metų, tačiau kitais metais, o ir bendrai per visus stebejimo metus, matyti, kad vyrų mirtingumas mažesnis, palyginti su moterų.

Europos narkotiku ir narkomanijos stebėsenos centro duomeni$\mathrm{mis}^{5}, 2017 \mathrm{~m}$. Europos Sajungos šalyse užregistruota daugiau kaip 8200 mirties atvejų, kai tiesiogine mirties priežastis buvo susijusi su vienos ar kelių narkotinių ir psichotropinių medžiagų (narkotikų) vartojimu. Šis skaičius būtų dar didesnis - 9400 mirčių, itraukus Norvegiją bei Turkiją. Nors atskirų ES šalių situacija skiriasi, bet apibendrinus visų šalių duomenis nustatyta, kad vyrų mirtys sudaro keturis penktadalius visų registruotu su narkotikais susijusių mirties atvejų. Daugelis mirčių buvo ankstyvos - mirtis dažniausiai ištiko nuo 30 iki 50 metų, o 9 iš 10 mirčių buvo susijusios su opioidų vartojimu.

Apibendrinus daugumos ES šalyse atliktų kohortinių tyrimų rezultatus, nustatyta, kad tirtų didelès rizikos narkotikų vartotojų mirtingumas sudare nuo 10 iki 30 mirčių 1000 asmens gyvenimo metų. Lietuvoje atlikto tyrimo duomenimis, narkotikų vartotojų mirtingumas sudare 19,7 mirties 1000 asmens gyvenimo metų. Didesnis nei Lie-

${ }^{5}$ Drug-related deaths and mortality in Europe. Interneto prieiga: http://www.emcdda. europa.eu/publications/rapid-communications/drug-related-deaths-in-europe-2018; žiūrèta 20210429.
2 lentelè. Mirusių tiriamųjų individualūs atvejai pagal mirties priežastis $(n=14)$.

\begin{tabular}{|c|c|c|c|}
\hline $\begin{array}{l}\text { Asmens } \\
\text { lytis }\end{array}$ & $\begin{array}{l}\text { Pagrindinè mirties prie- } \\
\text { žastis, nurodyta mirties } \\
\text { liudijime }\end{array}$ & $\begin{array}{l}\text { Kitos mirties priežastys ir informa- } \\
\text { cija, nurodyta mirties liudijime }\end{array}$ & $\begin{array}{c}\text { Mirties } \\
\text { metai }\end{array}$ \\
\hline Vyras & $\begin{array}{l}\text { Koronarų trombozè, nesukè- } \\
\text { lusi miokardo infarkto }\end{array}$ & Ūmus širdies veiklos nepakankamumas & 2019 \\
\hline Vyras & $\begin{array}{l}\text { Žmogaus imunodeficito viruso } \\
\text { (̌̌IV) ligos sąlygotos infekci- } \\
\text { nės ir parazitinės ligos }\end{array}$ & - & 2018 \\
\hline Vyras & $\begin{array}{l}\text { Kraujavimas, neklasifikuoja- } \\
\text { mas kitur }\end{array}$ & Sunkus hemoraginis šokas & 2018 \\
\hline Vyras & Inkstų ligų baigtys & $\begin{array}{l}\text { HD ( nuo } 202009 \text { 25). Potrombozinis } \\
\text { giliujų venų sindromas. Dvylikapirštės } \\
\text { žarnos opa. Anemija, nepatikslinta. Lè- } \\
\text { tinis virusinis C hepatitas. Metadono } \\
\text { programa. Lètinis inkstų funkcijos ne- } \\
\text { pakankamumas; uremija }\end{array}$ & 2020 \\
\hline Vyras & $\begin{array}{l}\text { Septicemija, sukelta auksinio } \\
\text { stafilokoko (Staphylococcus } \\
\text { aureus) }\end{array}$ & $\begin{array}{l}\text { Širdies nepakankamumas, lètinis prie- } \\
\text { širdžių virpėjimas, būklè po septinio } \\
\text { endokardito, MV protezavimo, TV } \\
\text { plastikos. Lètinis virusinis C hepa- } \\
\text { titas. S. aureus sukeltas sepsis; pneu- } \\
\text { monija; kvėpavimo nepakankamumas }\end{array}$ & 2019 \\
\hline Vyras & Septicemija, nepatikslinta & $\begin{array}{l}\text { Progresuojantis kvėpavimo ir širdies } \\
\text { nepakankamumas; sepsis. Letinė inkstų } \\
\text { liga, } 5 \text { stadija dèl lètinio glomerulonef- } \\
\text { rito. Hipoproteinemija. Abiejų blauzdų } \\
\text { trofinės opos. Psichikos ir elgesio sutri- } \\
\text { kimas dèl opioidu vartojimo, priklau- } \\
\text { somybės sindromas. Antrinė anemija }\end{array}$ & 2018 \\
\hline Vyras & Dilatacinè kardiomiopatija & Ūmus širdies veiklos nepakankamumas & 2018 \\
\hline Vyras & Asfiksija & $\begin{array}{l}\text { Uždusimas, kvėpavimo takams užsi- } \\
\text { kimšus skrandžio turiniu }\end{array}$ & 2019 \\
\hline Vyras & Metadonas & - & 2018 \\
\hline Moteris & Asfiksija & - & 2020 \\
\hline Moteris & $\begin{array}{l}\text { Kitos pneumonijos, kai sukè- } \\
\text { lëjas nenustatytas }\end{array}$ & $\begin{array}{l}\text { Narkomanija. ŽIV sukelta liga. Lè- } \\
\text { tinis virusinis C hepatitas. Lètinis } \\
\text { krūtinkaulio osteomielitas. Kvèpavimo } \\
\text { funkcijos, inkstų funkcijos, kraujotakos } \\
\text { nepakankamumas. Sepsis. Hemoraginė } \\
\text { būklè, nepatikslinta. Kraujavimas iš no- } \\
\text { sies. Toksinè encefalopatija }\end{array}$ & 2018 \\
\hline Moteris & $\begin{array}{l}\text { Kiti ir nepatikslinti narko- } \\
\text { tikai }\end{array}$ & 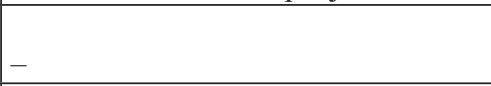 & 2020 \\
\hline Moteris & Septicemija, nepatikslinta & $\begin{array}{l}\text { Kojų giliujų venų flebitas. ŽIV. Psi- } \\
\text { chikos ir elgesio sutrikimas vartojant } \\
\text { opioidus. D. kojos celiulitas. Infekuota } \\
\text { poodinè hematoma. HCV infekcija } \\
\text { Ūmus kvèpavimo funkcijos nepakan- } \\
\text { kamumas; septinis šokas. Intoksikaci- } \\
\text { nis sindromas. Anemija. Metabolinė } \\
\text { acidozė }\end{array}$ & 2018 \\
\hline Moteris & Kardiomiopatija, nepatikslinta & Ūminis širdies veiklos sutrikimas & 2018 \\
\hline
\end{tabular}


tuvoje šis rodiklis buvo nustatytas tik Latvijoje ir Slovenijoje.

Europos šalių tyrimų duomenys rodo, kad didelès rizikos narkotikų vartotojai patiria nuo trijų iki septynių kartų didesnę mirties riziką, nei to paties amžiaus ir lyties asmenys standartinejje bendrojoje populiacijoje. Lietuvos tyrimo duomenimis, šis rodiklis dar blogesnis - net 12,7 karto. Europos tyrimų duomenys rodo, kad mirtys nuo apsinuodijimų (perdozavimo) narkotikais sudaro nuo trečdalio iki pusès visų didelès rizikos narkotikų vartotojų mirčių. Lietuvos atveju šis rodiklis buvo nustatytas mažesnis -14 procentų.

Lenkijoje atliktas kohortinis tyrimas, kurio metu buvo analizuojami 42700 tyrimo dalyvių duomenys (346 735 asmens gyvenimo metai) laikotarpiu nuo 2000 iki $2016 \mathrm{~m}$. Per tyrimo laikotarpi buvo užfiksuoti 5489 tiriamosios grupés asmenų mirties atvejai (sudaro 13 proc. visų tiriamujų), o apskaičiuotas mirtingumas yra 15,8 mirties 1000 asmens gyvenimo metų. Tyrimo duomenimis, beveik dešimtadalis tyrimo dalyvių mirè per 5-8 metus nuo ịsitraukimo ị tyrimą, o penktadalis dalyvių miré praejus 13-15 metų nuo jų įtraukimo ị tyrimą. Šiame tyrime mirtingumo rizika laikui bėgant buvo gana pastovi.

Austrijoje atliktas didelès apimties kohortinis tyrimas, apėmęs daugiau kaip 25 tūkst. pacientų, kuriems buvo taikomas pakaitinis gydymas opioidais nuo $2002 \mathrm{~m}$. sausio iki

3 lentelè. Mirtingumo rodikliai atskirais tyrimo stebejjimo metais (rodiklis / 1000 asm. m.).

\begin{tabular}{|c|c|c|c|}
\hline & $\begin{array}{l}\text { Mirtingu- } \\
\text { mas }\end{array}$ & 95 proc. $\mathrm{PI}$ & $\begin{array}{c}\text { Lietuvos bendras } \\
\text { mirtingumas }\end{array}$ \\
\hline \multicolumn{4}{|c|}{20181231} \\
\hline Vyrai & 22,8 & 9,$5 ; 54,7$ & 3,2 \\
\hline Moterys & 47,1 & 15,$2 ; 146,1$ & 1,1 \\
\hline Iš viso & 28,2 & 14,$1 ; 56,5$ & 2,1 \\
\hline \multicolumn{4}{|c|}{20191231} \\
\hline Vyrai & 17,7 & 5,$7 ; 55,0$ & 2,9 \\
\hline Moterys & 0 & 0 & 1,0 \\
\hline Iš viso & 13,8 & 4,$4 ; 42,7$ & 2,0 \\
\hline \multicolumn{3}{|c|}{20201231} & $\begin{array}{l}\text { Išankstiniais } \\
\text { duomenimis }\end{array}$ \\
\hline Vyrai & 6,1 & 0,$9 ; 43,3$ & 3,2 \\
\hline Moterys & 43,7 & 10,$9 ; 174,6$ & 1,1 \\
\hline Iš viso & 14,3 & 4,$6 ; 31,3$ & 2,2 \\
\hline \multicolumn{4}{|c|}{$20170101-20201231$} \\
\hline Vyrai & 16,3 & 8,$5 ; 31,3$ & \\
\hline Moterys & 31,6 & 13,$2 ; 76,0$ & \\
\hline Iš viso & 19,7 & 11,$7 ; 33,3$ & \\
\hline
\end{tabular}

2016 m. gruodžio mènesio. Dauguma šio tyrimo dalyvių jauni, apie 20-30 metu asmenys. Šio tyrimo metu buvo užfiksuota daugiau kaip 1500 tiriamujų mirties atvejų, iš kurių daugiau kaip trečdalis mirčių klasifikuojamos kaip tiesioginès asmenų mirtys dèl narkotinių ir psichotropinių medžiagų vartojimo. Apskaičiuotas tyrimo metu mirtingumas buvo 7,7 mirties 1000 asmens gyvenimo metų, o standartizuotas mirtingumas buvo 4,5. Tai reiškia, kad asmenys, dalyvavusieji pakaitinio gydymo opioidais programose, susidūrè su 4,5 karto didesne mirties rizika, nei to paties amžiaus ir lyties asmenys bendrojoje populiacijoje. Tyrimas parodè, kad asmenų, kurie dalyvavo pakaitinio gydymo opioidais programose, Austrijoje mirtingumas buvo mažesnis, palyginti su kitų šalių tyrimų rezultatais.

Latvijoje 2013-2017 m. atliktas bandomasis kohortinis tyrimas, apèmęs 2315 didelès rizikos narkotikų vartotojų (daugiausia opioidų ar stimuliantų, sintetinių kanapių vartotojai) nuo 15 iki 49 metų. Tyrimo metu buvo registruotos 182 mirtys, iš kurių 37 proc. buvo nulemtos išorinių priežasčių, o beveik trečdalis (29 proc.) mirčių ịvyko dèl širdies ir kraujagyslių ligų. Mirties priežasčiu analizè parodè, kad tik 15 mirties atvejų (8 proc.) bendrajame Latvijos mirčiu registre buvo registruotos kaip tiesioginès asmenų mirtys dèl narkotinių

4 lentelè. Standartizuoti rodikliai ir standartizuotas mirtingumo santykis.

\begin{tabular}{|c|c|c|c|c|}
\hline & $\begin{array}{l}\text { Standartizuo- } \\
\text { tas mirtin- } \\
\text { gumo santykis }\end{array}$ & $\begin{array}{l}95 \text { proc. } \\
\text { PI min }\end{array}$ & $\begin{array}{l}95 \text { proc. } \\
\text { PI max }\end{array}$ & $\begin{array}{l}\text { Standarti- } \\
\text { zuotas mir- } \\
\text { tingumas / } \\
1000 \text { asmens } \\
\text { metų }\end{array}$ \\
\hline \multicolumn{5}{|c|}{20181231} \\
\hline Vyrai & 13,2 & 5,5 & 31,6 & 19,6 \\
\hline Moterys & 66,3 & 21,4 & 205,5 & 43,6 \\
\hline Iš viso & 18,8 & 9,4 & 37,6 & 31,6 \\
\hline \multicolumn{5}{|c|}{20191231} \\
\hline Vyrai & 9,8 & 3,2 & 30,4 & 13,9 \\
\hline Moterys & 0,0 & - & - & 0,0 \\
\hline Iš viso & 8,8 & 2,8 & 27,2 & 6,9 \\
\hline \multicolumn{5}{|c|}{20201231} \\
\hline Vyrai & 3,3 & 0,5 & 23,5 & 4,4 \\
\hline Moterys & 58,1 & 14,5 & 232,3 & 39,4 \\
\hline Iš viso & 8,9 & 2,9 & 27,6 & 21,9 \\
\hline \multicolumn{5}{|c|}{ Viso tyrimo laikotarpio (2017 $0101-202012$ 31) } \\
\hline Vyrai & 9,1 & 4,7 & 17,5 & 13,3 \\
\hline Moterys & 43,2 & 18,0 & 103,7 & 30,5 \\
\hline Iš viso & 12,7 & 7,5 & 21,4 & 21,9 \\
\hline
\end{tabular}


ir psichotropinių medžiagų vartojimo (perdozavimo). Toks mažas tiesioginių mirčių, susijusių su narkotikais, skaičius leido daryti prielaidą, kad dalis iš 67 mirties atvejų, kurių priežastys klasifikuojamos kaip išorinės, buvo neteisingai registruotos (klasifikuotos) ir galèjo būti sukeltos mirtino apsinuodijimo narkotikais (perdozavimo). Dalis mirčių dèl apsinuodijimo narkotikais galèjo būti klaidingai užkoduotos kaip mirtys dẻl širdies ar kraujagyslių ligų (53 atvejai). Darytina išvada, kad registruotų 15 apsinuodijimo narkotikais (perdozavimo) atvejų yra minimalus skaičius ir parodo, kad tik tam tikra dalis mirtino apsinuodijimo narkotikais yra teisingai įtraukiama ị bendrą nacionalinę mirčių statistiką.

Svarbus kohortinių tyrimų rezultatų interpretavimą ribojantis veiksnys yra tas, kad faktiškai nemažą dalị mirties atvejų sudaro atvejai, kurių mirties priežastis yra nežinoma, nenustatyta ar nebūna nurodyta. Dèl to galimas nepakankamai tikslus apskaičiavimas, kokią kohortiniame tyrime nustatytų mirčiu dalį sudaro tiesioginès asmenų mirtys dèl narkotinių ir psichotropinių medžiagų vartojimo (mirtinas apsinuodijimas, priklausomybė ir kt.). Pastarojo Lenkijoje atlikto kohortinio tyrimo duomenimis, tik apie 5 proc. visu atvejų sudaro mirtys, klasifikuojamos kaip tiesiogiai susijusios su narkotikų vartojimu, nors nemažai mirties atvejų klasifikuoti (koduojami pagal TLK-10) tokiais ligos kodais, kurie leidžia daryti prielaidą, kad tai netinkamai užkoduotos mirtys, susijusios su narkotikų vartojimu - pavyzdžiui, dalis tokių atvejų pažymėti, kad mirties priežastis susijusi su širdies ir kraujagyslių ligomis (angl. cardiovascular disease), taip pat yra atvejų, kurie registruoti kaip „mirties priežastis nežinoma ar nenustatyta“, „klasifikuota kitur“ ar „savęs žalojimas" (angl. Self-harm). Lietuvos tyrime iš 14 analizuotų mirties atvejų nepasitaikè né vieno, kad asmens mirties liudijime būtų nenurodyta ar nežinoma mirties priežastis.

\section{Išvados}

1. Kohortinio narkotikų vartotojų Lietuvoje mirtingumo tyrimo tiriamają populiaciją sudare 231 asmuo, iš jų 179 vyrai ir 52 moterys. Tiriamuoju laikotarpiu (2018-2020 m.) analizuota 14 tyrimo dalyvių mirčių atvejų: devyni atvejai vyrų ir penki moterų. Tai sudare 6,1 proc. visų įtrauktų i tyrimą dalyvių - 5,0 proc. visų įtrauktų vyrų ir 9,6 proc. itrauktų moteru, santykis 1,9 karto.

2. Daugiausia mirusių tiriamujų buvo registruoti dèl psichikos ir elgesio sutrikimų vartojant opioidus - devyni asmenys (64 proc.). Bendras mirusiujų amžiaus vidurkis $-36,4$ metų, vyrų - 38,2 metų, moterų - 33,2 metų (palyginimui vyru vidutinè tikètina gyvenimo trukmé Lietuvoje $2019 \mathrm{~m}$. buvo 71,5 metų, moteru -81 metai).

3. Per visą tyrimo laikotarpi Lietuvos tirtos kohortos mirtingumas buvo 19,7/1000 asm. Standartizavus pagal amžių, standartu imant Europos populiaciją, nustatytas mirtingumas
21,9/1000 asmens metų, vyrų - 13,3/1000 asmens metų, o moterų 30,5/1000 asmens metų.

\section{Literatūra}

1. Drug-related deaths and mortality in Europe. Internetine prieiga: http://www.emcdda.europa.eu/publications/rapid-communications/drug-related-deaths-in-europe-2018. Žiūrèta 20210429.

2. European Drug Report 2020: Trends and Developments; Internetinė prieiga: https://www.emcdda.europa.eu/publications/edr/ trends-developments/2020. Žiūrèta 20210429.

3. Higienos institutas. Sveikatos statistika. Internetinè prieiga: https://stat.hi.lt/default.aspx?report_id=229. Žiūrèta 20210429.

4. Mortality cohort guidelines. Internetinè prieiga: https://www. emcdda.europa.eu/scientific-studies/2012/mortality-cohorts. Žiūrèta 20210429.

\section{DRUG-RELATED DEATHS AND MORTALITY IN LITHUANIA (COHORT STUDY) \\ R. Stukas, A. Beržanskytė, V. Dobrovolskij, L. Ignatavičiūtè, E. Jasaitis}

Keywords: drug users, mortality, cohort study.

Summary

The aim of the study was to determine the drug-related deaths and mortality in Lithuania and to analyze the causes of death.

Material and research methods. A prospective cohort study was performed. The target group of the research is citizens of the Republic of Lithuania, who in 2017 applied to Lithuanian health care institutions for mental and behavioral disorders when using drugs and psychotropic substances. Research data sources: Electronic health services and cooperation infrastructure information system (e-health). An additional source of data on individuals' drug use is the Information System for Monitoring Individuals who Appear to Personal Health Care Institutions for Mental and Behavioral Disorders When Using Drugs and Psychotropic Substances. Performing standardization procedures for test results in a controlled location - European standard population.

Outcome and conclusions. The study population of the cohort study of mortality of drug users in Lithuania consisted of 231 persons, of which 179 were older and 52 were female. During the study period (2018-2020), 14 deaths of study participants were analyzed: nine cases in men and five in women. This was 6.1 percent. 5.0\% of all participants included in the study. of all men included and 9.6 percent. included women, the ratio was 1.9 -fold. The highest number of deaths was due to mental and behavioral disorders due to opioid use - nine subjects (64\%). The total average age of deaths was 36.4 years, for men - 38.2 years, for women - 33.2 years (comparing men on average only with life expectancy in Lithuania in 2019 was 71.5 years, and for women - 81 years). During the whole study period, the mortality of the studied cohort in Lithuania was 19.7 / 1000 persons. Mortality is 21.9 per 1000 person-years, for men 13.3 per 1000 person-years for men and 30.5 per 1000 personyears for women, standardized by age for the European

Correspondence to: rimantas.stukas@mf.vu.lt

Gauta 2021-06-03 